\title{
PENGARUH PELATIHAN DAN MOTIVASI TERHADAP KINERJA KARYAWAN KASUS PERUSAHAAN DISTRIBUTOR ALAT BERAT
}

\author{
Thio Tjoen Hok, Aida Vitayala S. Hubeis, dan Sadikin Kuswanto \\ Management and Business, Postgraduate School of Bogor Agricultural University (IPB) \\ E-mail : thio2008@ymail.com
}

\begin{abstract}
ABSTRAK Tantangan untuk menghadapi persaingan pada bisnis alat-alat berat mengakibatkan PT ABC Tbk harus dapat meningkatkan kinerja divisi yang berhubungan dengan kegiatan purna jual (divisi service). Pelatihan dan motivasi karyawan dapat meningkatkan kinerja karyawan. Tujuan dari penelitian ini adalah (1) menganalisis tingkat persepsi karyawan terhadap pelatihan, motivasi, dan kinerja karyawan; (2) menganalisis pengaruh pelatihan terhadap kinerja karyawan; (3) menganalisis pengaruh motivasi terhadap kinerja karyawan; and (4) menganalisis pengaruh pelatihan dan motivasi terhadap kinerja karyawan. Penelitian ini menggunakan metode deskriptif melalui kuesioner. Jumlah sampel dalam penelitian ini adalah 71 karyawan divisi service pada PT ABC Tbk. Data diperoleh melalui penyebaran kuesioner, kemudian dianalisa menggunakan analisis regresi linier berganda. Hasil penelitian menunjukkan bahwa persepsi karyawan terhadap pelatihan, motivasi, dan kinerja tergolong baik. Hasil penelitian menggunakan analisis regresi linear berganda menunjukkan bahwa motivasi berpengaruh nyata terhadap kinerja, namun pelatihan tidak berpengaruh nyata terhadap kinerja. Berdasarkan hasil penelitian tersebut dan untuk meningkatkan kinerja karyawan, saran untuk manajemen adalah : (1) menyelenggarakan pelatihan yang sesuai dengan tugas dan tanggung jawab karyawan; (2) memerhatikan lingkungan kerja untuk menjaga motivasi karyawan; (3) menjaga semangat kerja karyawan.
\end{abstract}

Kata kunci : kinerja, motivasi, pelatihan, regresi linier berganda.

\section{INFLUENCE OF TRAINING AND MOTIVATION ON EMPLOYEE'S PERFORMANCE A STUDY OF HEAVY EQUIPMENT DISTRIBUTOR COMPANY}

\begin{abstract}
The challenge to be up against the business competition in heavy equipment sales drives PT ABC Tbk to improve the performance of its after-sales service (service division). Training and motivation of employees can increase employee performance. The purpose of this study were (1) to analyze employee's perception regarding training, motivation, and performance; (2) to analyzethe correlation of training to performance; (3) to analyze the correlation of motivation to performance; and (4) to analyze the correlation of training and motivation to performance. The research design used descriptive approach and questionnaire. Total samples of the study were 71 service division employees at PT ABC Tbk. Data were collected through questionnaire, then analyzed by using Multiple Linear Regression. The study showed that employee's perception regarding training, motivation and performance were categorized as good. The research result by regression found that motivation have significant effect on performance of employees, but training have not effect on performance of employees. Based on the results and for increasing employee's performance, the management is suggested to : (1) provide appropriate training in accordance with the roles and responsibility of employee; (2) concern about work environment in order to maintain employee's motivation; (3) maintain the working spirit of employee.
\end{abstract}

Keywords: motivation, multiple linear regression, performance, training.

\section{PENDAHULUAN}

Perkembangan dunia usaha serta persaingan yang semakin meningkat mengakibatkan adanya tuntutan terhadap kinerja sumber daya manusia (SDM) yang tinggi.Menurut Mathis dan Jackson (2003:113) ada tiga faktor utama yang memengaruhi individu dalam bekerja dan meningkatkan kinerjanya. Faktor-faktor tersebut adalah kemampuan (ability)individual untuk melakukan pekerjaan tersebut, tingkat usaha (effort) yang dicurahkan, dan dukungan (support) organisasi. Kinerja individu akan meningkat ketika kemampuan individu meningkat, ada usaha dari individu, dan adanya dukungan dari lingkungan organisasinya.

Tantangan untuk menghadapi persaingan pada bisnis penjualan alat-alat berat, serta turunnya penjualan alat-alat berat, mengakibatkan PT ABC harus dapat meningkatkan kinerja dari kegiatan purna jual yang menjadi andalan dari perusahaan penjual alat berat. Tuntutan untuk terus meningkatkan kinerja divisi purna jual (divisi Parts dan divisi Service), berakibat pada tuntutan kinerja karyawan yang berada pada kedua divisi tersebut dan dapat berdampak pada motivasi karyawan.

Berdasarkan permasalahan di atas studi kinerja karyawan di PT ABC perlu dilakukan untuk dapat menganalisis seberapa besar faktor pelatihan dan motivasi memengaruhi kinerja karyawan dan memberikan saran kepada perusahaan agar dapat meningkatkan kinerja karyawan di PT ABC.

Berdasarkan latar belakang tersebut maka beberapa permasalahan yang akan dikaji dalam penelitian ini adalah:

1. Bagaimana tingkat persepsi karyawan terhadap pelatihan, motivasi, dan kinerja karyawan di PT $\mathrm{ABC}$ ?

2. Apakah pelatihan berpengaruh terhadap kinerja karyawan di PT ABC?

3. Apakah motivasi berpengaruh terhadap kinerja karyawan di PT ABC?

4. Apakah pelatihan dan motivasi berpengaruh terhadap kinerja karyawan di PT ABC? 
Penelitian ini dilakukan di divisi service PT ABC. Sasaran penelitian dibatasi pada karyawan divisi service yang mendapatkan pelatihan dalam Service Officer Management Program (SOMP).

\section{Motivasi}

Motivasi adalah kekuatan atau dorongan bagi seseorang yang dapat menimbulkan semangat seseorang dalam melakukan suatu kegiatan.Mathis dan Jackson (2003:114) mengemukakan bahwa, motivasi (motivation) adalah keinginan dalam diri seseorang yang menyebabkan orang tersebut bertindak.

Motivasi kerja merupakan energi yang menggerakkan diri karyawan yang terarah serta dilakukan terus menerus untuk mencapai tujuan organisasi perusahaan, sehingga dapat diartikan sebagai keinginan atau kebutuhan-kebutuhan yang melatarbelakangi seseorang sehingga ia terdorong untuk bekerja. Motivasi merupakan bagian yang sangat penting dari kinerja karyawan (Nawab et al. 2011:1213).

\section{Teori-teori Motivasi}

Teori Dua Faktor dari Herzberg dalam Sunyoto (2012:195), mengemukakan bahwa ada dua faktor yang memengaruhi sikap seseorang terhadap pekerjaannya yang disebut dengan faktor kepuasan (satisfaction) dan faktor penyebab ketidakpuasan (dissastisfaction) yang berkaitan dengan suasana pekerjaan. Faktorfaktor kepuasan disebut juga motivator dan faktor ketidakpuasan disebut juga hygiene. Kedua faktor tersebut adalah:

1. Faktor motivator (motivator factor) berupa faktor:

a. Pencapaian.

b. Pengakuan.

c. Tanggung jawab.

d. Pengembangan.

e. Pekerjaan itu sendiri.

2. Faktor higienis (hygiene factor) dapat berbentuk:

a. Upah atau gaji.

b. Hubungan antar pekerja.

c. Kebijakan perusahaan.

d. Kondisi kerja.

e. Kualitas pengawasan.

f. Keamanan kerja.

\section{Pelatihan dan Pengembangan SDM}

Salah satu upaya untuk meningkatkan kualitas SDM sesuai dengan kebutuhan pekerjaan adalah dengan menyelenggarakan pelatihan dan pengembangan. Pelatihan akan meningkatkan nilai dari sebuah organisasi atau perusahaan ketika terjalin hubungan antara strategi pelatihan dengan tujuan dan sasaran organisasi serta strategi bisnis. Menurut Mathis dan Jackson (2003:301) pelatihan adalah sebuah proses dimana orang mendapatkan kemampuan untuk membantu pencapaian tujuan-tujuan organisasional.

\section{Proses Pelatihan dan Pengembangan SDM}

Penerapan pelatihan yang efektif dapat dilakukan melalui proses pelatihan secara sistematis. Pelatihan dan pengembangan SDM diharapkan oleh perusahaan agar dapat dilakukan dengan tepat sesuai dengan investasi yang ditanamkan dalam pelaksanaannya. Pendekatan secara sistematis dan strategik agar pelatihan dan pengembangan SDM memberikan dampak yang maksimum menurut Bohlander dan Snell (2010:307)terdiri dari empat fase yakni: 1) Needs Assessment (Perencanaan Kebutuhan Pelatihan), 2) Program Design (Perancangan Program Pelatihan), 3) Implementation (Pelaksanaan Pelatihan), 4) Evaluation (Penilaian Pelatihan).

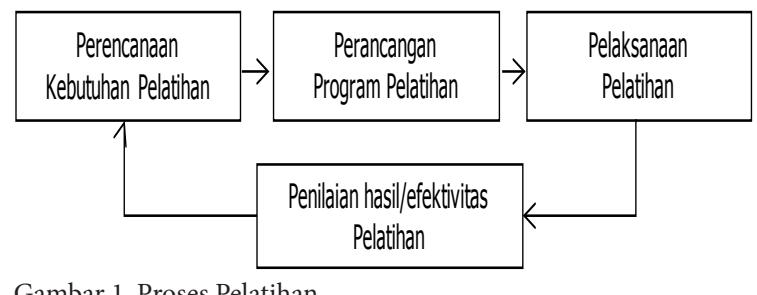

Perencanaan kebutuhan pelatihan dilakukan dengan menganalisis kebutuhan organisasi, kebutuhan pekerjaan serta individu karyawan. Hal tersebut dilakukan untuk dapat menentukan perbedaan antara kebutuhan organisasi dan pekerjaan dengan kompetensi yang dimiliki karyawan.

Dari perencanaan kebutuhan tersebut maka dirancang sebuah pelatihan yang mencakup tujuan dari pelatihan, kesiapan karyawan yang akan diberi pelatihan, prinsip-prinsip pelatihan, kemampuan dari pelatih serta materi pelatihan sesuai dengan kebutuhan.

Menurut Bangun (2012:205) dalam merancang pelatihan, terdapat tiga faktor penting yang perlu diperhatikan, yaitu:

1. Kesiapan peserta pelatihan.

2. Kemampuan pelatih.

3. Materi pelatihan.

Pelaksanaan pelatihan, terlebih dahulu melakukan pengujian terhadap metode-metode yang akan digunakan untuk memastikan bahwa metode yang digunakan sesuai dengan kebutuhan.

Penilaian pelatihan dilakukan untuk melihat hasil yang dicapai dengan membandingkan setelah dilakukan pelatihan dengan tujuan-tujuan yang diharapkan.

\section{Kinerja}

Menurut Mangkuprawira (2011:121),kinerja adalah hasil kerja yang dapat dicapai oleh seseorang atau kelompok orang dalam suatu perusahaan sesuai dengan wewenang dan tanggung jawab masing-masing dalam upaya pencapaian tujuan perusahaan secara legal, tidak melanggar hukum dan tidak bertentangan dengan moral atau etika.

Penilaian kinerja dilakukan dengan membandingkan antara aktual pelaksanaan dengan rencana kinerja yang telah disepakati sebelumnya, bukan digunakan untuk memaksa karyawan bekerja lebih keras dan lebih baik. Menurut Bangun (2012:231),penilaian kinerja dapat dilakukan dengan membandingkan hasil kerja yang dicapai karyawan dengan standar 
pekerjaan. Bila hasil kerja yang diperoleh sampai atau melebihi standar pekerjaan dapat dikatakan kinerja seorang karyawan termasuk pada kategori baik. Demikian sebaliknya, seorang karyawan yang hasil pekerjaannya tidak mencapai standar pekerjaan termasuk pada kinerja yang tidak baik atau berkinerja rendah.

Menurut Bangun (2012:234) kinerja karyawan dapat diukur melalui:

1. Jumlah pekerjaan.

2. Kualitas pekerjaan.

3. Ketepatan waktu.

4. Kehadiran.

5. Kemampuan kerjasama.

Visi adalah pandangan yang jauh ke depan dari sebuah perusahaan. Visi merupakan arahan dari pimpinan perusahaan tentang tujuan perusahaan di masa yang akan datang. Visi perusahaan mengandung pernyataan tentang gambaran yang ingin dicapai oleh perusahaan di masa yang akan datang. Dari visi tersebut maka dirumuskan sebuah misi yang akan dijalani dalam setiap aktivitas dan penetapan tujuan dan sasaran perusahaan.

Misi perusahaan adalah pernyataan tentang hal-hal yang harus dikerjakan dalam usaha untuk mewujudkan visi. Misi perusahaan adalah merupakan tujuan dan alasan mengapa perusahaan tersebut ada.

Untuk mencapai apa yang telah dicanangkan dalam visi dan misi perusahaan, diperlukan perumusan strategi perusahaan. Strategi perusahaan secara menyeluruh kemudian diturunkan ke dalam strategistrategi pada setiap bagian yang ada diperusahaan. Strategi tersebut akan menciptakan keunggulan tersendiri bagi perusahaan dibandingkan dengan pesaingnya. Strategi-strategi tersebut antara lain strategi penjualan, strategi keuangan, strategi sumber daya manusia. Salah satu strategi sumber daya manusia adalah bagaimana perusahaan atau organisasi dapat meningkatkan kinerjanya melalui peningkatan kinerja dari SDM nya. Kerangka pemikiran konseptual tersebut dapat dilihat pada Gambar 2

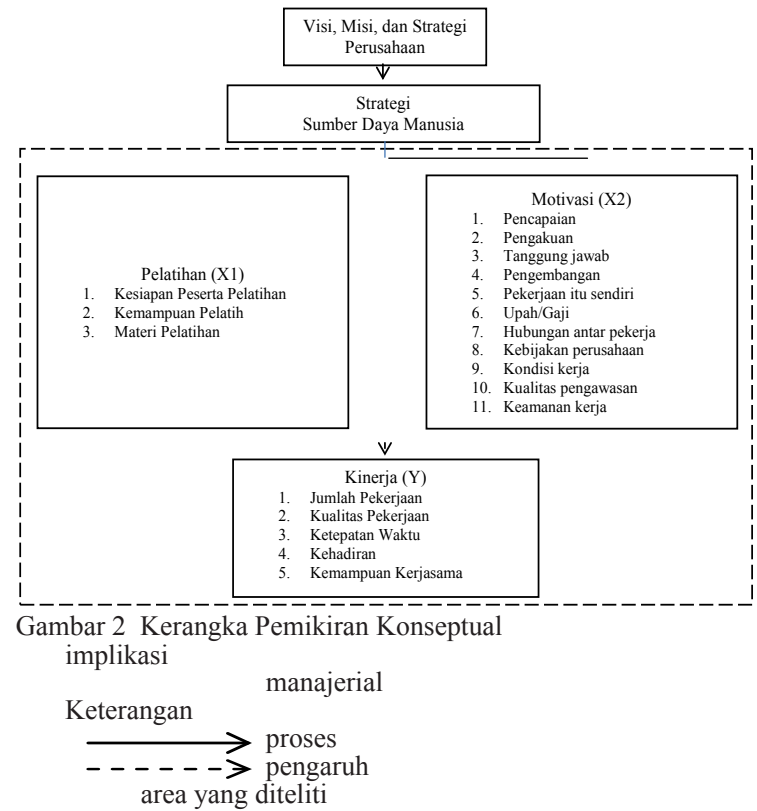

\section{METODE}

Jenis penelitian ini adalah penelitian deskriptif dengan menggunakan survei yang bertujuan untuk memeroleh gambaran suatu kondisi atau keadaan tentang pengaruh pelatihan dan motivasi terhadap kinerja karyawan PT ABC. Arikunto (2010:282) menyatakan bahwa penelitian deskriptif adalah penelitian yang dimaksudkan untuk menyelidiki keadaan, kondisi atau hal-hal lain, yang hasilnya dipaparkan dalam bentuk laporan penelitian.

Penelitian dengan teknik survei didefinisikan sebagai penelitian yang dilakukan terhadap populasi dan sampel dari variabel yang digunakan diteliti melalui pengumpulan data secara kuantitatif menggunakan kuesioner. Kemudian data yang terkumpul akan diolah dan dianalisa melalui teknik statistik untuk menganalisis secara umum tentang pengaruh pelatihan dan motivasi terhadap kinerja karyawan.

\section{Jenis dan Sumber Data}

Pengumpulan data dilakukan selama 2(dua) bulan, mulai bulan Juli hingga bulan Agustus 2013. Data yang diperlukan dalam penelitian ini terdiri dari 2 (dua) jenis data, yaitu data primer dan data sekunder. Data primer diperoleh melalui kuesioner yang akan disebarkan terhadap karyawan divisi service PT ABC yang termasuk dalam Service Officer Management Program (SOMP) sebagai responden dalam penelitian. Selanjutnya data tersebut akan direkapitulasi dan disesuaikan dengan teknik analisis yang digunakan. Sedangkan data sekunder diperoleh dari data-data yang telah tersedia dan telah dipergunakan oleh perusahaan untuk keperluan lainnya serta data yang diperoleh dari literatur dan sumber-sumber lainnya yang relevan terhadap penelitian ini.

\section{Teknik Pengolahan dan Analisis Data}

Alat analisis yang digunakan dalam penelitian ini adalah :

1. Analisis Rentang Kriteria

2. Analisis Regresi Berganda

Analisis rentang kriteria digunakan untuk melihat persepsi responden terhadap motivasi, pelatihan, dan kinerja yang ditunjukkan dalam kuesioner. Adapun langkah yang perlu dilakukan adalah melakukan pengelompokkan jawaban dan menentukan bobot sesuai dengan urutan jawaban. Menurut Umar (2005:226) tahapan untuk menentukan rentang kriteria adalah:

1. Pengelompokkan Jawaban

Kuesioner diberikan dalam bentuk pernyataanpernyataan. Setiap pernyataan dalam kuesioner memiliki lima pilihan jawaban yang memiliki nilai bobot tertentu. Bobot indikator yang paling rendah, diberi angka 1 (satu), sedangkan untuk bobot yang paling tinggi, diberikan angka 5 (lima). Kuesioner yang terkumpul dikelompokkan sesuai dengan jawaban yaitu:

Bobot 1: STS (Sangat tidak Setuju) 
Bobot 2: TS (Tidak Setuju)

Bobot 3: N (Netral)

Bobot 4 : S (Setuju)

Bobot 5: SS (Sangat Setuju)

2. Perhitungan Skor

Setelah jawaban dikelompokkan, kemudian dihitung skor setiap komponen, dengan mengalikan jumlah frekuensi dari masing-masing komponen variabel dengan bobot tersebut di atas.

3. Menentukan Rataan Skor

Hasil perhitungan skor tersebut kemudian masingmasing dibagi dengan jumlah responden.

4. Memberikan Penilaian

Langkah berikutnya adalah memberikan penilaian terhadap tiap kriteria yang dinilai dalam kuesioner, sehingga dapat ditarik kesimpulan mengenai tanggapan responden terhadap variabel yang diteliti. Untuk menentukan nilai digunakan rumus:

Di mana: RK = Rentang Kriteria.

$$
\begin{array}{ll}
\mathrm{m} & =\text { skala jawaban terbesar. } \\
\mathrm{n} & =\text { skala jawaban terkecil. } \\
\mathrm{K} & =\text { Jumlah kelas. }
\end{array}
$$

Berdasarkan rumus di atas, maka dapat diperoleh rentang kriteria sebagai berikut:

$$
\mathrm{RK}=\frac{5-1}{5}=0.80
$$

Rentang kriteria pada penelitian dapat dilihat pada Tabel 1 .

Tabel 1 Rentang kriteria

\begin{tabular}{lc}
\hline Pernyataan responden & Interval \\
\hline Sangat Setuju (SS) & $4.21-5.00$ \\
Setuju (S) & $3.41-4.20$ \\
Netral (N) & $2.61-3.40$ \\
Tidak Setuju (TS) & $1.81-2.60$ \\
Sangat Tidak Setuju (STS) & $1.00-1.80$ \\
\hline
\end{tabular}

Analisis regresi berganda digunakan untuk mengukur pengaruh antara lebih dari satu variabel bebas terhadap variabel terikat.Formulasi yang dipergunakan adalah sebagai berikut:

$$
\begin{aligned}
& \mathrm{Y}=\mathrm{b}_{0}+\mathrm{b}_{1} \mathrm{X}_{1}+\mathrm{b}_{2} \mathrm{X}_{2}+\mathrm{e} \\
& \text { Dimana: } \\
& \mathrm{Y}=\text { Kinerja. } \\
& \mathrm{X}_{1}=\text { Pelatihan. } \\
& \mathrm{X}_{2}=\text { Motivasi. } \\
& \mathrm{b}_{0}=\text { Konstanta. } \\
& \mathrm{b}_{1}, \mathrm{~b}_{2}=\text { Koefisien regresi variabel } \mathrm{X} . \\
& \mathrm{e}=\text { Error. }
\end{aligned}
$$

\section{Uji F (uji serempak)}

Uji serempak (uji F) digunakan untuk mengetahui pengaruh variabel bebas yaitu pelatihan dan motivasi secara serempak terhadap kinerja karyawan dengan tingkat keyakinan $95 \%(\alpha=0.05)$.

Hipotesis dalam uji $\mathrm{F}$ ini adalah:

$\mathrm{H}_{0}: \mathrm{b}_{1}, \mathrm{~b}_{2}=0$; artinya pelatihan dan motivasi secara serempak tidak berpengaruh terhadap kinerja karyawan.

$\mathrm{H}_{1}: \mathrm{b}_{1}, \mathrm{~b}_{2} \neq 0$; artinya pelatihan dan motivasi secara serempak berpengaruh terhadap kinerja karyawan.

Rumus yang digunakan untuk menguji hipotesis tersebut adalah :

$$
F=\frac{R^{2} /(k-1)}{\left(1-R^{2}\right)(N-k)}
$$

Di mana:

$\mathrm{R}^{2}=$ Koefisien determinasi.

$\mathrm{N}=$ Jumlah sampel (observasi).

$\mathrm{K}=$ Jumlah parameter/koefisien regresi plus konstanta.

Nilai $\mathrm{F}_{\text {hitung }}$ akan dibandingkan dengan nilai $\mathrm{F}_{\text {tabel }}$.

Kriteria pengambilan keputusannya adalah:

Jika nilai $\mathrm{F}_{\text {hitung }}>\mathrm{F}_{\text {tabel }}$, maka $\mathrm{H}_{0}$ ditolak pada $\alpha=0.05$.

Jika nilai $\mathrm{F}_{\text {hitung }}<\mathrm{F}_{\text {tabel }}$, maka $\mathrm{H}_{0}$ diterima pada $\alpha=0.05$.

Uji t (uji parsial)

Uji parsial (uji t) digunakan untuk mengetahui secara parsial pengaruh variabel bebas yaitu pelatihan dan motivasi terhadap kinerja karyawan.

Hipotesis dalam uji t ini adalah:

$\mathrm{H}_{0}: \mathrm{b}_{1}=0$; artinya pelatihan dan motivasi secara parsial tidak berpengaruh terhadap kinerja karyawan.

$\mathrm{H}_{1}: \mathrm{b}_{1} \neq 0$; artinya pelatihan dan motivasi secara parsial berpengaruh terhadap kinerja karyawan.

Nilai $t_{\text {hitung }}$ akan dibandingkan dengan nilai $t_{\text {tabel }}$. Kriteria pengambilan keputusannya adalah:

Jika nilai $\mathrm{t}_{\text {hitung }}>\mathrm{t}_{\text {tabel }}$, maka $\mathrm{H}_{0}$ ditolak pada $\alpha=0.05$.

Jika nilai $\mathrm{t}_{\text {hitung }}<\mathrm{t}_{\text {tabel }}$, maka $\mathrm{H}_{0}$ diterima pada $\alpha=0.05$.

Sugiyono (2009) menyatakan bahwa nilai $t_{\text {hitung }}$ dapat diperoleh dengan menggunakan rumus:

\begin{tabular}{|c|c|}
\hline Karakteristik Responden & Persen tase \\
\hline \multicolumn{2}{|l|}{ Jab atan } \\
\hline Quality Assurance & $13 \%$ \\
\hline Site Technical Eng in eer & $6 \%$ \\
\hline Instructor & $56 \%$ \\
\hline Technical ad $v$ iso $r$ & $4 \%$ \\
\hline Technical Officer & $21 \%$ \\
\hline \multicolumn{2}{|l|}{ Usia } \\
\hline$\leq 30$ & $65 \%$ \\
\hline $31-40$ & $17 \%$ \\
\hline $41-50$ & $13 \%$ \\
\hline$>50$ & $5 \%$ \\
\hline \multicolumn{2}{|l|}{ Jen is Kelamin } \\
\hline Pria & $100 \%$ \\
\hline \multicolumn{2}{|l|}{ Pendidikan Terak $h$ ir } \\
\hline SMU/SMK & $27 \%$ \\
\hline Diploma tiga (D3) & $49 \%$ \\
\hline Sarjana strata satu ( $\mathrm{S} 1)$ & $24 \%$ \\
\hline \multicolumn{2}{|l|}{ Masa Kerja } \\
\hline $1-5$ & $63 \%$ \\
\hline $6-10$ & $14 \%$ \\
\hline $11-15$ & $0 \%$ \\
\hline $16-20$ & $6 \%$ \\
\hline$>20$ & $17 \%$ \\
\hline
\end{tabular}

$$
\begin{aligned}
& \mathbf{t}=\frac{r_{p} \sqrt{n-2}}{1-r_{p}^{2}} \\
& \text { Di mana: } \\
& t \quad=\text { Nilai } t_{\text {hitung. }} . \\
& r_{p} \quad=\text { Korelasi parsial yang ditemukan. } \\
& n \quad=\text { Jumlah sampel. }
\end{aligned}
$$

\section{HASIL DAN PEMBAHASAN}

\section{Karakteristik Responden}

Responden dalam penelitian ini adalah karyawan divisi service di PT ABC yang telah mendapatkan pelatihan dalam program Service Officer Management Program (SOMP). Karyawan yang termasuk dalam program SOMP tersebut adalah karyawan dengan jabatan sebagai Quality Assurance (QA), Site Technical Engineer (STE), Instructor, Technical Advisor serta Technical Officer.

Tabel 2 Karakteristik responden berdasarkan demografi 
Profil responden dijelaskan berdasarkan data demografi yang meliputi jabatan, usia, jenis kelamin, pendidikan terakhir, dan masa kerja. Data selengkapnya dapat dilihat pada Tabel 2.

\section{Proses dan Hasil Analisis Data}

Uji validitas dan reliabilitas dilakukan terhadap 71 kuesioner yang kembali dari 80 kuesioner yang dibagikan. Hasil uji reliabilitas menunjukkan bahwa nilai cronbach's alpha adalah 0.861 untuk variabel pelatihan, 0.962 untuk variabel motivasi, dan 0.843 untuk variabel kinerja yang menunjukkan bahwa kuesioner yang digunakan dalam penelitian ini reliabel. Suatu variabel akan dinyatakan handal (reliable) jika nilai cronbach alpha> 0.60 (Noor 2011:165).

Sedangkan hasil uji validitas menunjukkan bahwa seluruh instrumen penelitian dinyatakan valid karena seluruh variabel indikator yang diuji memiliki nilai Pearson Correlation lebih besar dari 0.3 (Arikunto 2010:214). Dengan validnya seluruh instrumen uji maka hasil yang didapat adalah benar-benar sesuai dengan kondisi yang terjadi dilapangan dan tidak perlu menghilangkan satupun variabel indikator.

\section{Persepsi Responden}

Persepsi responden terhadap pelatihan adalah baik dengan nilai rataan skor 3.89. Persepsi responden terhadap kesiapan peserta pelatihan memiliki rataan skor 4.04 yang menunjukkan bahwa responden memahami pelatihan yang akan diikuti karena informasi tentang pelatihan sudah diberitahukan terlebih dahulu kepada karyawan sebelum hari pelaksanaan.

Persepsi responden terhadap kemampuan pelatih memiliki nilai rataan skor 3.74 yang menunjukkan bahwa responden memiliki persepsi bahwa para pelatih memiliki kualifikasi yang sesuai dengan materi yang diberikan, para pelatih memiliki kompetensi sesuai dengan materi yang akan diberikan serta memahami materi yang akan disampaikan kepada peserta.

Selanjutnya, responden setuju bahwa materi pelatihan yang diberikan mudah dipahami oleh peserta pelatihan, sesuai dengan rencana pelatihan. Persepsi responden terhadap pelatihan memiliki rataan skor 3.87 .

Persepsi responden terhadap motivasi memiliki rataan skor 3.79 yang artinya dipersepsikan baik. Suasana kerja terjalin dengan baik, antar karyawan saling memberikan dorongan dalam pekerjaan dan informasi perihal penyelesaian pekerjaan mudah diperoleh dari rekan kerja sehingga responden memiliki persepsi sangat baik terhadap hubungan antar pekerja yang ditunjukkan dengan nilai rataan skor 4.34 .

Responden memiliki persepsi sangat baik untuk indikator kehadiran dengan rataan skor 4.28 dan indikator kemampuan kerjasama dengan rataan skor 4.30. Hal ini menunjukkan bahwa karyawan memiliki kinerja yang baik yang terlihat dari tingkat kehadiran yang tinggi, karyawan memiliki keinginan untuk menyelesaikan pekerjaan mereka walaupun untuk itu mereka harus bekerja lembur. Karyawan sering menawarkan ide kepada rekan kerja yang lain dalam menyelesaikan pekerjaan dan bekerja sama dalam tim untuk tujuan perusahaan.

\section{Pengujian Hipotesis}

Berdasarkan hasil pengolahan data diperoleh hasil seperti yang ditunjukkan pada Tabel 3.

Tabel 3 Hasil uji regresi motivasi dan pelatihan

\begin{tabular}{cccc}
\hline \multirow{2}{*}{ Model } & \multicolumn{2}{c}{$\begin{array}{c}\text { Unstandardized } \\
\text { Coefficients }\end{array}$} & $\begin{array}{c}\text { Standardized } \\
\text { Coefficients }\end{array}$ \\
\cline { 2 - 4 } & $B$ & Std.Error & Beta \\
\hline (Constant) & 1.628 & 0.449 & \\
$X_{1}$ & 0.149 & 0.107 & 0.139 \\
$X_{2}$ & 0.482 & 0.086 & 0.559 \\
\hline
\end{tabular}

Berdasarkan Tabel 3 maka persamaan regresi linear berganda dalam penelitian ini adalah sebagai berikut :

$$
\mathrm{Y}=1.628+0.149 \mathrm{X}_{1}+0.482 \mathrm{X}_{2}
$$

Koefisien regresi $X_{1}$ (pelatihan) bernilai positif 0.149 artinya bahwa ketika $X_{1}$ naik satu satuan maka $Y$ akan meningkat sebesar 0.149 satuan dengan asumsi cateris paribus. Karena koefisien positif artinya untuk meningkatkan $\mathrm{Y}$ maka $\mathrm{X}_{1}$ harus ditingkatkan.

Koefisien regresi $\mathrm{X}_{2}$ (motivasi) bernilai positif 0.482 artinya bahwa ketika $X_{2}$ naik satu satuan maka $Y$ akan meningkat sebesar 0.482 satuan dengan asumsi cateris paribus. Karena koefisien positif artinya untuk meningkatkan $\mathrm{Y}$ maka $\mathrm{X}_{2}$ harus ditingkatkan.

Sedangkan untuk melihat korelasi dari kemampuan variabel pelatihan dan motivasi dalam pengaruhnya terhadap variabel kinerja dapat dilihat pada Tabel 4.

Tabel 4 Nilai koefisien determinasi ( $R$ Square)

\begin{tabular}{cccccc}
\hline Model & $R$ & $R$ Square & $\begin{array}{c}\text { Adjusted } \\
\text { R Square }\end{array}$ & $\begin{array}{c}\text { Std. Error of } \\
\text { the Estimate }\end{array}$ & $\begin{array}{c}\text { Durbin- } \\
\text { Watson }\end{array}$ \\
\hline 1 & $0.615^{\mathrm{a}}$ & 0.378 & 0.359 & 0.29928 & 1.971 \\
\hline
\end{tabular}

Berdasarkan Tabel 4 nilai $\mathrm{R}$ Square adalah 0.378 yang artinya bahwa kemampuan variabel pelatihan $\left(\mathrm{X}_{1}\right)$ dan motivasi $\left(\mathrm{X}_{2}\right)$ dapat menjelaskan pengaruhnya terhadap variabel kinerja $(\mathrm{Y})$ sebesar $37.8 \%$ dan sisanya $62.2 \%$ dijelaskan oleh variabel bebas lain di luar model yang tidak termasuk dalam penelitian.

Uji F dilakukan untuk mengetahui tingkat signifikansi pengaruh dari seluruh variabel bebas yaitu pelatihan dan motivasi terhadap variabel terikat yaitu kinerja karyawan. Hasil uji ini dapat dilihat dari Tabel 5.

Tabel 5 Hasil pengujian hipotesis secara serempak

\begin{tabular}{clccccc}
\hline \multirow{2}{*}{ Model } & & $\begin{array}{c}\text { Sum of } \\
\text { Squares }\end{array}$ & $d f$ & $\begin{array}{c}\text { Mean } \\
\text { Square }\end{array}$ & F & Sig. \\
\hline \multirow{2}{*}{1} & Regression & 3.697 & 2 & 1.849 & 20.641 & $0.000^{\mathrm{a}}$ \\
& Residual & 6.091 & 68 & 0.090 & & \\
& Total & 9.788 & 70 & & & \\
\hline
\end{tabular}


Dari hasil uji ini diperoleh nilai signifikansi (p-value) sebesar $0.000<\alpha=0.05$ maka tolak $\mathrm{H}_{0}$ artinya pelatihan dan motivasi secara serempak berpengaruh terhadap kinerja karyawan atau berarti model fit.

Untuk mengetahui pengaruh variabel bebas yaitu pelatihan dan motivasi terhadap kinerja karyawan secara parsial dilakukan uji t. Hasil uji ini dapat dilihat pada Tabel 6 .

Tabel 6 Hasil pengujian hipotesis secara parsial

\begin{tabular}{cccccc}
\hline \multirow{2}{*}{ Model } & \multicolumn{2}{c}{$\begin{array}{c}\text { Unstandardized } \\
\text { Coefficients }\end{array}$} & $\begin{array}{c}\text { Standardized } \\
\text { Coefficients }\end{array}$ & \multirow{2}{*}{$t$} & Sig. \\
\cline { 2 - 4 } & $\mathrm{B}$ & Std.Error & Beta & & \\
\hline (Constant) & 1.628 & 0.449 & & 3.622 & .001 \\
$\mathrm{X}_{1}$ & 0.149 & 0.107 & 0.139 & 1.385 & .171 \\
$\mathrm{X}_{2}$ & 0.482 & 0.086 & 0.559 & 5.591 & .000 \\
\hline
\end{tabular}

Dari Tabel 6 diperoleh hasil sebagai berikut :

1. Nilai $t_{\text {hitung }}$ untuk variabel pelatihan $\left(X_{1}\right)$ sebesar 1.385 atau signifikansi ( $p$-value) sebesar $0.171>$ $\alpha=0.05$ maka terima $\mathrm{H}_{0}$ artinya variabel pelatihan $\left(\mathrm{X}_{1}\right)$ tidak berpengaruh nyata terhadap variabel Kinerja (Y).

2. Nilai $t_{\text {hitung }}$ untuk variabel motivasi $\left(\mathrm{X}_{2}\right)$ sebesar 5.591 atau signifikansi ( $\mathrm{p}$-value) sebesar $0.000<$ $\alpha=0.05$ maka tolak $\mathrm{H}_{0}$ artinya variabel motivasi $\left(\mathrm{X}_{2}\right)$ berpengaruh nyata terhadap variabel Kinerja (Y).

Dari karakteristik responden dapat dilihat bahwa berdasarkan jabatan, jumlah responden terbanyak berada pada jabatan sebagai Instructor yang jumlahnya sebanyak 40 responden atau 56\% dari total 71 responden. Hal ini sesuai dengan kebutuhan pada divisi service yang memerlukan tenaga untuk melatih para mekanik alat-alat berat yang jumlahnya lebih banyak dibandingkan dengan karyawan pada divisi lain.

Berdasarkan usia, mayoritas responden pada usia di bawah 30 tahun yaitu mencapai 46 responden atau $65 \%$ dari total 71 responden. Hal ini menunjukkan bahwa sebagian besar responden yang termasuk dalam program SOMP adalah karyawan pada usia muda yang masih memiliki potensi untuk dikembangkan di masa mendatang.

Seluruh responden pada penelitian ini adalah berjenis kelamin laki-laki, hal ini disebabkan karena karakteristik pekerjaan pada jabatan yang termasuk dalam SOMP banyak berhubungan dengan hal-hal teknis yang berkaitan dengan alat-alat berat yang membutuhkan kekuatan fisik.

Berdasarkan pendidikan terakhir, responden dengan pendidikan terakhir minimal Diploma tiga (D3) sebanyak 52 orang atau $73 \%$. Hal ini menunjukkan bahwa Service Officer memiliki potensi yang besar untuk dapat ditingkatkan di masa mendatang.

Masa kerja responden paling banyak adalah antara 1-5 tahun yaitu sebanyak 45 orang atau $63 \%$ yang artinya responden didominasi oleh karyawan yunior. Hal ini sesuai dengan perkembangan bisnis perusahaan pada masa satu dekade terakhir yang banyak memerlukan tenaga-tenaga baru untuk jabatan sebagai Service Officer.
Berdasarkan hasil pengujian hipotesis yang menyatakan bahwa variabel pelatihan tidak berpengaruh nyata terhadap variabel kinerja, peneliti melakukan wawancara terhadap para atasan dari responden untuk melakukan konfirmasi atas hasil penelitian tersebut. Hasil wawancara menyatakan bahwa bagi karyawan yunior dengan masa kerja kurang dari lima tahun yang merupakan bagian terbesar dari responden, proses pendampingan akan lebih meningkatkan kinerja karyawan dibandingkan dengan pelatihan. Hal ini terjadi karena karyawan yunior belum memiliki pengalaman untuk meningkatkan kepercayaan dirinya walaupun telah mendapatkan pelatihan.

\section{SIMPULAN}

Karyawan memiliki persepsi yang baik terhadap pelatihan, baik dalam hal peserta pelatihan memiliki kesiapan dalam mengikuti pelatihan, dalam hal kemampuan pelatih dalam memberikan pelatihan, maupun terhadap materi pelatihan yang diberikan. Karyawan memiliki persepsi yang baik terhadap motivasi dalam hal pencapaian kerja karyawan, pengakuan dari perusahaan, tanggung jawab terhadap pekerjaan, pengembangan karyawan, pekerjaan yang diberikan kepada karyawan, kebijakan perusahaan, kondisi lingkungan tempat bekerja, kualitas pengawasan dari atasan, serta jaminan kerja. Persepsi hubungan antar pekerja sangat baik. Karyawan memiliki persepsi kinerja yang baik dalam hal jumlah pekerjaan, kualitas pekerjaan, serta ketepatan waktu dalam menyelesaikan pekerjaan. Sedangkan tingkat kehadiran dan kemampuan kerjasama, karyawan memiliki persepsi sangat baik.

Pelatihan tidak berpengaruh nyata terhadap kinerja karyawan. Hal ini karena proses pelatihan mulai dari perencanaan kebutuhan pelatihan, perancangan program pelatihan, pelaksanaan pelatihan, dan penilaian pelatihan belum dilaksanakan secara baik.

Motivasi berpengaruh secara signifikan terhadap kinerja karyawan, karena faktor-faktor dalam meningkatkan motivasi telah dilakukan dengan baik.

Pelatihan dan motivasi secara serempak mempengaruhi kinerja setiap tahapan pelatihan perlu dilakukan dengan baik. Dalam perencanaan pelatihan, identifikasi kebutuhan individu perlu disesuaikan dengan uraian pekerjaan karyawan yang dilakukan pada saat analisa pekerjaan. Perlu dibuat rencana pelaksanaan pelatihan yang berisi uraian pelatihan, tujuan pelatihan, pelatih yang akan memberikan pelatihan, serta waktu pelaksanaan pelatihan sebelum pelaksanaan pelatihan.

Dalam pelaksanaan pelatihan perlu dilakukan penggabungan baik on the job training, off the job training maupun secara online menggunakan e-learning.

Dalam penilaian pelatihan perlu ditingkatkan hingga ke tingkat perilaku maupun hasil pelatihan, dan dilakukan secara konsisten.

Kemampuan para atasan dalam memberikan bimbingan, arahan, maupun pujian perlu lebih ditingkatkan, karena akan memberikan dampak terhadap motivasi karyawan. Perusahaan dapat menyelenggarakan pelatihan bagi para atasan untuk hal ini. 
Program-program untuk meningkatkan hubungan antar pekerja perlu terus diupayakan agar motivasi karyawan tetap terjaga sehingga dapat terus meningkatkan kinerja karyawan.

Perusahaan perlu terus meningkatkan sistem penggajian dan memberikan penjelasan secara transparan kepada karyawan.

Penjelasan terhadap perkembangan perusahaan maupun masa depan perusahaan perlu untuk terus disampaikan kepada karyawan agar karyawan merasa terjamin kelangsungan pekerjaannya.

\section{DAFTAR PUSTAKA}

Arikunto S. 2010. Prosedur Penelitian suatu Pendekatan Praktik Edisi Revisi. Jakarta (ID): Rineka Cipta.

Bangun W. 2012.Manajemen Sumber Daya Manusia. Jakarta (ID): Erlangga Pr.

Bohlander GW, Snell SA. 2010. Principles of Human Resource Management, $16^{\text {th }}$ International ed. South-Western (US): Cengage Learning.
Mangkuprawira S. 2011. Strategi Efektif Mengelola Karyawan. Bogor (ID): IPB Pr.

Mathis RL, Jackson JH. 2003. Human Resources Management, $10^{\text {th }} \mathrm{ed}$. Ohio (US): Thomson Learning.

Nawab S, Bhatti KK, Shafi K. 2011. Effect of motivation on employees performance, Interdisciplinary Journal of Contemporary Research in Business. 3(3):1209-1216.

Noor J. 2011. Metodologi Penelitian : Skripsi, Tesis, Disertasi, dan Karya Ilmiah. Jakarta (ID): Kencana Prenada Media Group.

Sugiyono. 2009. Metode Penelitian Administrasi. Bandung (ID): Alfabeta.

Sunyoto D. 2012.Manajemen Sumber Daya manusia. Yogyakarta (ID): CAPS.

Umar H. 2005. RisetSumber Daya Manusia dalamOrganisasi. Jakarta (ID): PT Gramedia Pustaka Utama. 